\title{
67 år gammel mann med parestesier i høyre arm
}

\author{
Skuldersmerter og parestesier i armen kan skyldes alt fra ufarlige \\ og forbigående tilstander til mer alvorlige sykdommer. En avventende \\ holdning kan ha prognostisk betydning for pasienten.
}

Se kommentar side 2615 og kunnskapsprøve på www.tidsskriftet.no/quiz

En 67 år gammel mann ble innlagt $i$ lokalsykehus grunnet smerter $i$ thorax. Han hadde $i$ over 20 år periodevis hatt smerter $i$ brystveggen, uavhengig av aktivitetsnivå. Disse episodene var vanligvis av et par timers varighet, men var blitt hyppigere og av sterkere intensitet. Han var i fullt arbeid, men hadde tidvis vært sykmeldt grunnet depresjon. Han var normalvektig, brukte ingen faste medisiner og hadde vært dagligrøyker fra 20-årsalderen.

De foregående tre månedene hadde han hatt en prikkende, stikkende følelse i høyre arm samt smerter $i$ skulderbladet. Han beskrev dette som «tusen knivstikk i armen». Symptomene hadde ikke tidligere vært utredet. Av journalførende lege ble parestesiene beskrevet til å innbefatte hele armen, uten sensibilitetstap eller kraftsvekkelse. EKG og infarktmarkører var upåfallende.

Listen over differensialdiagnoser ved armog skuldersmerter er lang, og inkluderer thoraxapertursyndrom (thoracic outlet syndrome). Ved utgangen av brysthulen, mellom øverste ribbein og kragebeinet (thoracic outlet), er det mulighet for kompresjon av nerver (plexus brachialis) og kar. Forklaringen er i mange tilfeller at scalenusmuskulaturen er blitt unormalt stram, ofte pga. innflammasjonstilstander i skulderen eller nakkeskade. Andre årsaker kan være kragebeinsfraktur, ribbeanomalier og dislokasjon av caput humeri. De vanligste symptomene ved thoraxapertursyndrom er smerter, nummenhet, prikking og tyngdefølelse $\mathrm{i}$ den involverte armen. Symptomene er ofte vage og generaliserte, og det er ubehag i hele armen. Det kan også være nakkesmerter og hodepine (1).

Røntgen thorax (fig 1) tatt rutinemessig ved innkomst viste en oppfylling i høyre lungetopp. CT collum/thorax/abdomen avdekket en ca. $6 \mathrm{~cm}$ stor svulst apikalt i høyre lunge (fig 2a, b). Det var ingen tegn til patologisk forstørrede lymfeknuter eller andre svulster. Bildene viste i tillegg emfysemforandringer og et stort abdominalt aortaaneurisme.
Oppfyllinger apikalt i thorax kan representere primærsvulster utgående fra lunge, pleura, thyreoidea eller larynx. Andre årsaker kan være infeksjoner, metastaser, myelomatose, lymfom, aneurisme i a. subclavia og amyloidose i pleura (2).

Pasienten ble bronkoskopert - uten patologiske funn. Det ble ikke funnet maligne celler ved børstecytologi. Han ble henvist til videre utredning ved Oslo universitetssykehus, Rikshospitalet, hvor CT-veiledet finnålsaspirasjonscytologi viste maligne celler forenlig med ikke-småcellet karsinom. CT thorax viste mulig infiltrasjon interkostalt ved de tre øverste ribbeina, men uten sikker skjelettdestruksjon. MR cervikotorakalcolumna viste at svulsten lå an mot de øverste tre torakale virvler, uten beinaffeksjon, men det ble påvist innvekst i tilgrensende costa.

Pasienten hadde altså lungekreft. Svulsten betegnes som Pancoasts tumor pga. beliggenhet i lungetoppen, med innvekst i brystvegg. Perifer beliggenhet bidrar til at bronkoskopi gir positiv cytologi kun i 10-20\% av tilfellene (3). En Pancoast-svulst er derimot lett tilgjengelig for perkutane transtorakale nålebiopsier, med en suksessrate på opp mot $95 \%(2)$.

Pancoasts syndrom er en betegnelse på en rekke symptomer assosiert med Pancoastsvulster og inkluderer smerter i skulder og arm, Horners syndrom og svakhet og atrofi i håndmuskulaturen (2). Pancoast-svulstens perifere lokalisasjon gjør at pasienten sjelden har symptomer som hoste, hemoptyse og dyspné.

Ved slike svulster er skuldersmerter ofte det presenterende symptom, forårsaket av innvekst i plexus brachialis, lungepleura og/ eller de øverste ribbeina på affisert side. Pasienten kan ha utstrålende smerter til hode, nakke, aksille eller fremre brystvegg og, som hos vår pasient, til skulder og arm. Affeksjon av C8-rot og nedre del av plexus brachialis kan gi nedsatt kraft $\mathrm{i}$ armen, mens smerter svarende til ulnare segment i underarm og hånd tyder på affeksjon av T1-roten (4). Dersom tumor affiserer de sympatiske nervebanene, kan pasienten utvikle Horners syndrom, med unilateral miose, ptose og nedsatt perspirasjon (anhydrose). Dette er blitt rapportert hos opptil $50 \%$ av dem med Pancoasts syndrom (2). Hos et mindre antall kan man også se affeksjon av n. phrenicus eller $n$. recurrens. Noen utvikler også v. cava superior-syndrom, som innebærer kompresjon av v. cava med symptomer som dyspné, ødem i ansikt, hals og overekstremiteter samt økte kartegninger. MR-unders økelse er CT-undersøkelse overlegen ved vurdering av involvering av tilliggende bløtvevsstrukturer og bør derfor inkluderes i utredningen (5).

Pasienten fikk strålebehandling (fig 3) i form av 25 sesjoner à 2 Gy daglig med kurativt siktemål. I løpet av disse fem ukene fikk han også to kurer kjemoterapi (cisplatin og etopsid - PV-kur). Første kur ble gitt ved start av strålebehandlingen, andre kur tre uker senere. På grunn av nøytropen feber etter første kur ble kjemoterapidosen ved andre kur redusert med $25 \%$. Etter behandlingen var smertene i høyre skulder og arm borte.

Flere studier viser at pasienter med Pancoastsvulster som får kurativt rettet multimodalt regime med strålebehandling, kjemoterapi og kirurgi har markant bedre overlevelse enn dem som kun får strålebehandling og kirurgi (6). Hos vår pasient ble to kurer platinabasert kjemoterapi gitt i kombinasjon med strålebehandling, i samsvar med en amerikansk multisenterstudie der det ble rapportert om en femårsoverlevelse på 44 \% (7).

Fire uker etter avsluttet behandling ble pasienten reinnlagt til operativ behandling med kurativ intensjon. Ny MR collum/thorax

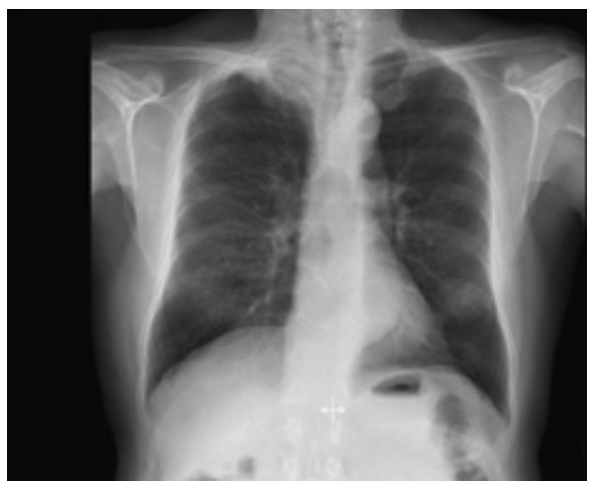

Figur 1 Røntgen thorax før start av behandling. Tumor i høyre lungetopp 

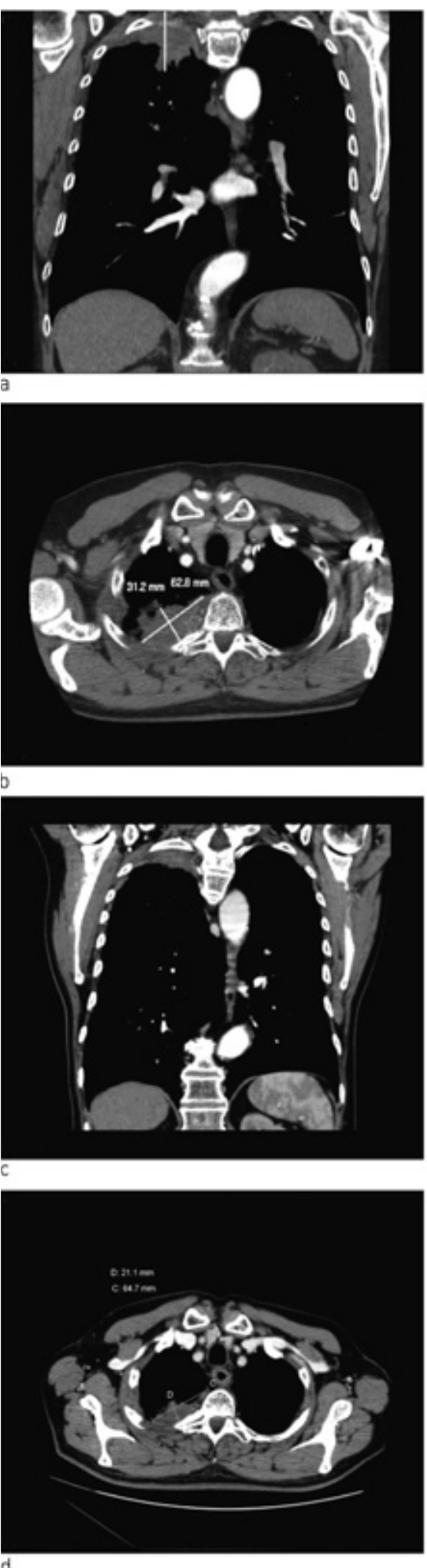

Figur 2 a, b) CT thorax av tumor ved diagnosetidspunktet med innvekst i tilliggende strukturer. c, d) Størrelsesreduksjon av tumor etter kombinert kjemo-radio-terapi

viste fortsatt sannsynlig innvekst i 2. og 3 . høyre costa samt mulig tumoraffeksjon av Th 2. Det var ikke tegn til affeksjon av plexus brachialis. CT viste at tumor hadde skrumpet (fig 2c, d). Det ble også utført PET-CT (fig 4). Denne var uegnet til vurdering av lokale forhold pga. pasientens nylig gjennom- gåtte strålebehandling, men viste ingen tegn til viabelt tumorvev $i$ thoraxveggen eller malignitet andre steder i kroppen. Basert på PET-CT-funnene ble pasienten etter tverrfaglig vurdering bedømt som operabel, og det ble gjennomført lobektomi av høyre overlapp.

For å kunne vurdere operabiliteten på et best mulig grunnlag bør evaluering etter kjemoradioterapi inkludere både $\mathrm{CT}$ og MR thorax, og helst også PET-CT-undersøkelse, som har vist høyere sensitivitet og spesifisitet enn CT-undersøkelse ved stadieinndeling og deteksjon av ekstrakraniale fjernmetastaser hos pasienter med lungekreft av ikkesmåcellet type (8). Dersom pasienten er operabel, bør inngrepet foretas innen fire uker. Om operasjon ikke er aktuelt, anbefales videreføring av stråleterapi til $66 \mathrm{~Gy}$, ev. i kombinasjon med ytterligere en PV-kur. Ved lokal progrediering eller fjernmetastaser bør annen kjemoterapi eller palliativ bestråling av metastasene vurderes.

Tumor ble peroperativt klassifisert som T1NOMO, stadieinndelingen var således ikke i samsvar med preoperativ MR-beskrivelse. Det ble utført glandeltoalett subkarinalt samt mot oesophagus. Histologisk unders $\varnothing-$ kelse viste at det forelå et mucinøst adenokarsinom (ikke-småcellet) uten fri reseksjonsrand mot pleura. Det ble ikke påvist tumorceller i noen av 11 uttatte lymfeknuter. Postoperativt oppsto det komplikasjoner i form av pneumothorax, med vedvarende luftlekkasje i thoraxdren. Dette medførte fire ukers drenbehandling.

Ved kontroll to måneder postoperativt hadde pasienten hatt et vekttap på $i$ overkant av $20 \%$ siden behandlingsstart. Han hadde høyt CRP-nivå og stigende SR. CT thorax viste væskelokulament med luftbobler apikalt $i$ høyre lunge. Han var fremdeles sliten etter behandlingen og ønsket ikke noe nytt kirurgisk inngrep. Bredspektret antibiotikabehandling ble igangsatt, hvorpå han kom seg fint, med normalisering av infeksjonsvariablene.

Ved kontroll ni måneder etter operasjonen ble det utført CT thorax og caput på bakgrunn av thoraxsmerter og hodepine. CT caput var negativ, CT thorax viste en brem apikalt på høyre side, som mest sannsynlig representerte arrforandringer etter operasjonen. Pasienten kontrolleres foreløpig hver tredje måned ved lokalsykehusets onkologiske poliklinikk.

\section{Diskusjon}

Maligne svulster i lungetoppen har fått sitt eponym etter den amerikanske radiologen Henry Pancoast (1875-1939), som i 1932 publiserte en studie med sju slike pasienter (9). Historisk har disse svulstene vært assosiert med svært dårlig prognose, og de var lenge ansett som inoperable. Pancoastsvulster utgjør under $5 \%$ av alle lungekreft-

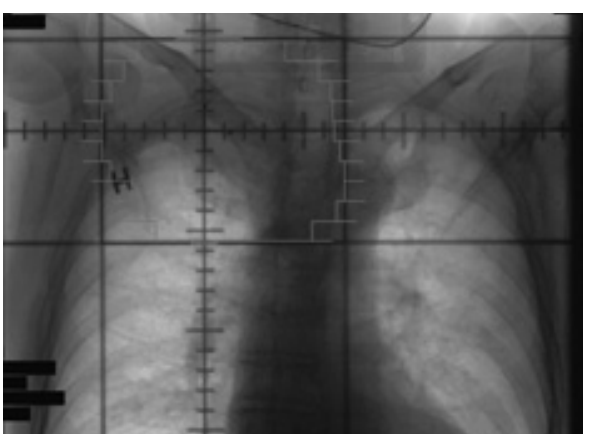

Figur 3 Strålefeltet innbefattet tumor med margin

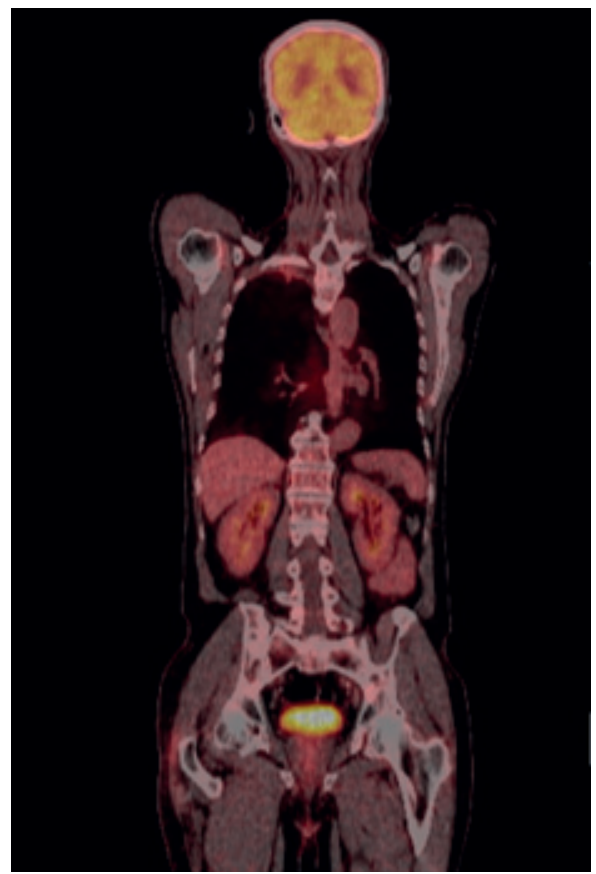

Figur 4 PET-CT viser lett økt opptak i tumor $i$ høyre lunge, uten opptaksøkning $i$ thoraxvegg. Det er svakt opptak i lungevev baktil i overlappen basalt for dette, sannsynlig sekvele etter bestråling

tilfeller (3) og er nesten alltid av ikke-småcellet type (2).

På grunn av beliggenheten kan disse svulstene være vanskelig å oppdage ved konvensjonell røntgenundersøkelse. Det ses ofte kun apikal pleurafortykkelse med asymmetri av lungetoppene. Fordi skuldersmerter er et av de mest typiske symptomene, blir mange initialt behandlet for antatte muskel-skjelett-plager, og symptomene kan vedvare i måneder før videre utredning igangsettes. Forsinket diagnose bidrar til at de fleste av disse svulstene oppdages $i$ et avansert stadium - noe som har konsekvenser for overlevelsen (2). I et materiale fra Attar og medarbeidere var median overlevelse ved T3-sykdom 36,8 måneder, 6,4 måneder ved T4-sykdom (10).

Pancoast-svulster bør utredes grundig før oppstart av multimodal behandling, da slik kurativt rettet terapi forutsetter lokalisert sykdom. Den hyppigste lokalisasjon ved 
fjernmetastaser er hjernen, og hjernemetastaser forekommer hos opptil $40 \%$ under eller etter gjennomgått behandling (11). Utredningen bør derfor inkludere MR caput $i$ tillegg til MR-undersøkelse av tumorområdet både før og etter kjemoradioterapi for preoperativ vurdering av tumorutbredelse.

Behandling av lungekreft representerer en utfordring, idet man knapt har sett bedret overlevelse de siste 40 årene, til tross for bedre diagnostikk, mer avanserte kirurgiske teknikker og strålebehandling. Pancoastsvulster kan ubehandlet gi et stort smerteproblem pga. lokal innvekst i nerver og andre strukturer. Det er derfor grunn til å behandle aggressivt, selv der kun pallativ behandling er indisert. Dersom man ikke oppnår tilfredsstillende smertelindring med multimodal eller konvensjonell palliativ behandling, kan cervikal kordotomi vurderes (12).

Studier publisert i 1960-årene påviste en viss bedring i resultater hos Pancoast-pasienter som fikk strålebehandling etterfulgt av kirurgisk reseksjon (13). De siste årene har flere rapporter pekt på at cellegiftbehandling gitt sammen med strålebehandling før operasjon øker sannsynligheten for komplett patologisk respons og bedret overlevelse uten uakseptable bivirkninger (6). Man kan dermed ha mulighet for kurasjon på tross av avansert sykdom.

Det er i regi av Norsk lungekreftgruppe planlagt en fase 2-studie som tilsvarer behandlingsopplegget denne pasienten mottok. Selv om det gjenstår flere spørsmål når det gjelder stråledosering, cellegifttype og -dosering, vil implementering av multimodal behandling i Norge forhåpentlig bidra til bedret overlevelse for denne pasientgruppen.

\section{Camilla M.T. Sagerup}

camsa@radiumhospitalet.no

Odd Terje Brustugun

Kreftklinikken

Oslo universitetssykehus, Radiumhospitalet 0310 Oslo

\section{Lars Jørgensen}

Kirurgisk avdeling

Oslo universitetssykehus, Rikshospitalet

Pasienten har gitt samtykke til at artikkelen blir publisert.

\section{Oppgitte interessekonflikter: Ingen}

\section{Litteratur}

1. Sanders RJ, Hammond SL, Rao NM. Diagnosis of thoracic outlet syndrome. J Vasc Surg 2007; 46 601-4.

2. Arcasoy SM, Jett JR. Superior pulmonary sulcus tumors and Pancoast's syndrome. N Engl J Med 1997: 337: $1370-6$

3. Narayan S, Thomas CR jr. Multimodality therapy for Pancoast tumor. Nat Clin Pract Oncol 2006; 3 : 484-91.

4. Rusch VW. Management of Pancoast tumours Lancet Oncol 2006; 7: 997-1005.
5. Webb WR Gatsonis C. Zerhouni EA et al. CT and MR imaging in staging non-small cell bronchogenic carcinoma: report of the Radiologic Diagnostic Oncology Group. Radiology 1991; 178: 705-13.

6. Rusch VW, Giroux DJ, Kraut MJ et al. Induction chemoradiation and surgical resection for super ior sulcus non-small-cell lung carcinomas: long term results of Southwest Oncology Group Trial 9416 (Intergroup Trial 0160). J Clin Oncol 2007; 25 313-8

7. Rusch VW, Giroux DJ, Kraut MJ et al. Induction chemoradiation and surgical resection for nonsmall cell lung carcinomas of the superior sulcus: initial results of Southwest Oncology Group Trial 9416 (Intergroup Trial 0160). J Thorac Cardiovasc Surg 2001; 121: 472-83

8. MacManus M, Hicks RJ. The use of positron emission tomography (PET) in the staging/evaluation. treatment, and follow-up of patients with lung cancer: a critical review. Int J Radiat Oncol Biol Phys 2008; 72: 1298-306.

9. Pancoast H. Superior pulmonary sulcus tumor: tumor characterized by pain, Horner's syndrome. destruction of bone and atrophy of hand muscles. JAMA 1932; 99: 1391-6

10. Attar S, Krasna MJ, Sonett JR et al. Superior sulcus (Pancoast) tumor: experience with 105 patients. Ann Thorac Surg 1998; 66: 193-8.

11. Shah H, Anker CJ, Bogart J et al. Brain: the common site of relapse in patients with pancoast or superior sulcus tumors. J Thorac Oncol 2006; 1 : $1020-2$

12. Rosomoff HL, Brown CJ, Sheptak P. Percutaneous radiofrequency cervical cordotomy: technique. J Neurosurg 1965; 23: 639-44.

13. Shahian DM. Contemporary management of superior pulmonary sulcus (Pancoast) lung tumors. Curr Opin Pulm Med 2003; 9: 327-31.

Manuskriptet ble mottatt 3.3. 2009 og godkjent 16.9. 2009. Medisinsk redaktør Anne Kveim Lie.

\section{Sjeldne tilstander er sjeldne}

«Sjeldne tilstander er sjeldne,» pleide

min allmennpraktikerkollega å si. Før han fortsatte: «Men det er veldig mange av dem.» Han likte å imponere studentene som var utplassert hos oss med å vise frem pasienter med Fallots tetrade (3-6 per 10000 fødsler) (1), Marfans syndrom (prevalens $0,02 \%$ ) (1) eller medfødt diafragmabrokk (1 per 3 000-4 000 fødsler, svarende til én hvert 100. år i min praksispopulasjon) (2). Studentene smilte høflig, men forbeholdent. Sjeldne sykdommer hadde de sett på Rikshospitalet, nå var de i allmennpraksis for å lære om de alminnelige.

Klinisk diagnostikk innebærer å tolke hvert trinn i den diagnostiske prosessen: sykehistorien, den fysiske undersøkelsen samt ulike prøvesvar. Hvor mye resultatet av hvert av disse trinnene endrer sannsynligheten for at pasienten har en gitt sykdom (posttestsannsynlighet), avhenger sterkt av den antatte prevalensen av sykdommen i den gitte populasjon (pretestsannsynlighet) (3). I allmennpraksis er pasientpopulasjonen lav- prevalent for alle alvorlige sykdommer, og det store flertall av de helseproblemene som presenteres for legen er uskyldige og/eller selvbegrensende. I startfasen av en alvorlig sykdom er symptomene dessuten ofte identiske med plagene ved de mindre alvorlige. Pasienten som er beskrevet i kasuistikken, hadde hatt perioder med smerter i brystveggen gjennom 20 år. De foregående tre månedene hadde han vært plaget av smerter $i$ høyre skulderblad, beskrevet som «tusen knivstikk i armen», i tillegg til en prikkende følelse. Dette viste seg altså å skyldes en Pancoast-tumor - en malign svulst i høyre lungetopp.

«Fordi skuldersmerter er et av de mest typiske symptomene (ved Pancoast-tumor), blir mange initialt behandlet for antatte muskel-skjelett-plager, og symptomene kan vedvare $\mathrm{i}$ måneder før videre utredning igangsettes,» skriver forfatterne. En japansk undersøkelse av 48 pasienter med Pancoasttumor viste at det gikk i gjennomsnitt 164 dager fra symptomdebut til behandlingsstart
(38-400 dager) (4). En tredel av «forsinkelsen» skyldtes at pasientene ikke søkte lege før etter en tid, to tredeler (14 til 349 dager) at legene brukte tid på å stille diagnosen - i alle ledd av utredningskjeden.

Til tross for omfattende søk har jeg ikke klart å finne opplysninger om hvor ofte Pancoast-tumor forekommer, men den beskrives som sjelden. Problemer i nakke, skulder og arm er derimot i en norsk undersøkelse angitt å stå for $7 \%$ av konsultasjonene i allmennpraksis (5), hvilket for mitt vedkommende betyr ca. 240 pasientkontakter i året. Skal jeg så begynne å tenke på at disse kan ha en Pancoast-tumor og utrede med tanke på dette? Nei, selvsagt ikke. Myalgier, tendinitter og bursitter skal fortsatt være fremst i bevisstheten.

Men - som min kollega så riktig sa - det er mange av de sjeldne tilstandene. Så hvordan skal vi klare å fange dem opp blant alle trivialitetene? Jeg tror allmennleger ofte kommer på sporet av alvorlige tilstander ved at vi får et inntrykk av at «her er det noe som 